\title{
JURISDICTIONAL UNCERTAINTY AND PIPELINES: IS A JUDICIAL SOLUTION POSSIBLE?
}

\author{
STEVEN A. KENNETT*
}

This article addresses the problem of jurisdictional uncertainty over pipelines. Some commentators have suggested that judicial interpretations of $\boldsymbol{s}$. 92(10)(a) of the Canadian Constitution, the federal works and undertakings power, are inadequate and have proven unworkable. The author outlines these deficiencies, but maintains that the existing legal tests can be reformulated to provide greater jurisdictional certainty. The key, the author maintains, is to acknowledge the conceptual distinction between works and undertakings. Then, for each case a two-step analysis is proposed, in which the court must first identify the work or undertaking in question and then classify it as intraprovincial or extraprovincial. The implications of this new model are then explored in the practical context of the NOVA pipeline system.
Le présent article traite des problemes de compétence incertaine concernant les pipelines. Selon certains analystes, les interprétations judiciaires de l'art. 92(10)(a) de la Loi constitutionnelle, le pouvoir fédéral en matière de travaux et entreprises, sont inadéquates et se sont avérées irréalisables. L'auteur démontre leurs insuffisances, mais soutient que les critères juridiques existants peuvent être reformulés de manière à accrottre la certitude quant d̀ la compétence. La clé, aux dires de l'auteur, consiste à reconnaitre la distinction conceptuelle entre travaux et entreprises. Il propose ensuite une analyse en deux étapes pour chaque cas. La cour doit d'abord identifier les travaux ou les entreprises en cause, et déterminer s'ils sont du ressort interprovincial ou extra-provincial. Les implications de ce nouveau modele sont ensuite examinées dans le contexte pratique du réseau pipelinier NOVA.

\section{TABLE OF CONTENTS}

I. INTRODUCTION $\ldots \ldots \ldots \ldots \ldots \ldots \ldots \ldots \ldots \ldots 54$

II. THE TRANSPORTATION POWER $\ldots \ldots \ldots \ldots \ldots \ldots \ldots 556$

III. THE "INTEGRAL" AND "ESSENTIAL" TESTS ......... 559

IV. WORKS AND UNDERTAKINGS $\ldots \ldots \ldots \ldots \ldots \ldots \ldots . \ldots 56$

V. JURISDICTION OVER WORKS $\ldots \ldots \ldots \ldots \ldots \ldots \ldots \ldots 564$

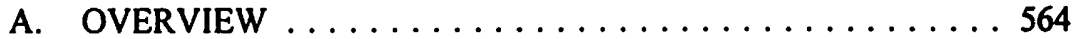



C. WORKS AND THE "NEXUS" APPROACH ......... 568

D. DETERMINING WHAT CONSTITUTES A WORK ...... 569

E. EXTRAPROVINCIAL UNDERTAKINGS AND WORKS .. 570

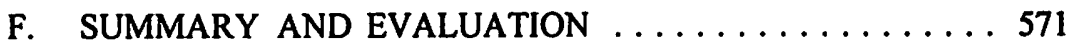

VI. JURISDICTION OVER UNDERTAKINGS $\ldots \ldots \ldots \ldots \ldots \ldots 572$



B. THE WINNER ANALYSIS AND IDENTIFICATION OF THE UNDERTAKING $\ldots \ldots \ldots \ldots \ldots \ldots \ldots . \ldots 74$



D. SUMMARY AND EVALUATION $\ldots \ldots \ldots \ldots \ldots \ldots 585$

VII. THE NOVA EXAMPLE $\ldots \ldots \ldots \ldots \ldots \ldots \ldots \ldots \ldots \ldots 58$

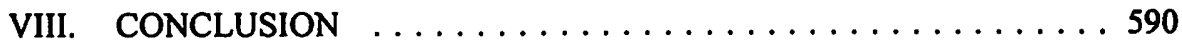

Research Associate, Canadian Institute of Resources Law. The research for this article was made possible by a grant from the Alberta Law Foundation. The excellent research assistance of KayLynn Goelzer-Litton is also gratefully acknowledged. 


\section{INTRODUCTION}

Despite an extensive body of relevant case law and apparently well-settled legal principles, pipelines continue to be the subject of jurisdictional uncertainty and litigation. A significant number of cases involving the transportation power - the constitutional basis for pipeline jurisdiction - have been before the Supreme Court of Canada and the Federal Court of Appeal over the past three decades.' The National Energy Board (NEB) has also confronted the issue of pipeline jurisdiction on several occasions in recent years, resulting in controversial rulings and vigorous dissenting opinions. ${ }^{2}$ In 1996, two of these decisions were overturned by the Federal Court of Appeal, ${ }^{3}$ and the NEB itself initiated a reference to that court on a jurisdictional question arising from another pipeline application. ${ }^{4}$ Pipeline projects currently in the planning stages have also been identified as raising difficult jurisdictional issues. ${ }^{3}$ It is thus apparent that, for a broad range of fact situations, the principles developed to date by the courts provide inadequate guidance in determining which level of government has authority over pipelines. The NEB, in particular, is clearly searching for a resolution of the ongoing jurisdictional confusion.

Proponents of pipeline projects also find themselves in a very unsatisfactory position. Uncertainty about which level of government has authority raises the initial question of where to direct project applications. It also opens the door to third-party intervention in applications and the consequent risk of significant delay while litigation runs its course. In some instances, projects may be redesigned, or proponents changed, in order to address jurisdictional issues and facilitate regulatory review. ${ }^{6}$ Delays could even result in project cancellation if market conditions change or a competitive advantage is lost. All of this uncertainty and legal manoeuvring is expensive and time-consuming.

In light of the seemingly unending stream of pipeline cases, it is reasonable to ask whether a judicial solution to jurisdictional uncertainty is possible. Pessimism in this

These cases are discussed below.

2 Reasons for Decision In the Matter of Altamont Gas Transmission Canada Ltd. (February 1991), No. GHW-1-92 (N.E.B.) [hereinafter Altamont]; Reasons for Decision In the Matter of TransGas Ltd. (October 1993), No. GH-R-1-93 (N.E.B.); Reasons for Decision In the Matter of Westcoast Energy Inc. (May 1995), No. GH-5-94 (N.E.B.); and Reasons for Decision In the Matter of Niagara Gas Transmission Lid. (September, 1995), (N.E.B.) [hereinafter Niagara Gas].

Wesicoast Energy Inc. v. Canada (National Energy Board), [1996] 2 F.C. 263 (C.A.) thereinafter Westcoast] [An application for leave to appeal this decision was allowed by the Supreme Court of Canada ((1996), 138 D.L.R. (4th) vii (S.C.C.))]; Consumers' Gas Co. v. National Energy Board (1996), 195 N.R. 150 (F.C.A.) [hereinafter Consumers' Gas].

- See Reasons for Decision In the Matter of Novagas Clearinghouse Pipelines Ltd. (January 1996), No. GH-1-96 (N.E.B.) at 1 [hereinafter Pech Creek]. A motion by the Government of Alberta to quash the reference filed by the National Energy Board was successful. See In the Matter of the National Energy Board Act (14 January 1997), No. A-482-96 (F.C.A.); Alberta v. Westcoast Energy (14 January 1997), No. A-558-96 (F.C.A.). Developments, Current Issues and a Suggested Mechanism for Reducing Turbulence in the Buffer Zone" (1997) 35 Alta. L. Rev. 389 at 401. 
regard is not surprising. Rowland Harrison, for example, has argued that the "pall of uncertainty over the dividing line between federal and provincial jurisdiction in relation to interprovincial pipelines and their associated facilities" is not amenable to judicial resolution. ${ }^{7}$ He summarizes this position as follows:

While there now seems to be a consensus that the relevant legal principles are both settled and clear, ... the application of such principles is as problematic as ever. Therefore, in the absence of a final judicial ruling specific to each particular facility, the jurisdictional status of many facilities will continue to be uncertain. ${ }^{8}$

Since resolving uncertainty in the pipeline sector through endless facility-by-facility litigation is unsatisfactory for all of the parties involved, Harrison proposes a political solution that relies on administrative techniques of interdelegation.9

Harrison's recommendation of an administrative mechanism "to mitigate the consequences of the uncertainty that is an inherent and permanent feature of our federal system"10 suggests that, according to his analysis, the constitutional provision establishing the transportation power is incapable of satisfactory interpretation and application. While there is clearly an empirical basis for this view, it nonetheless remains a remarkable conclusion regarding the role - and limitations - of constitutional law in Canadian federalism. The implication is that, at least in relation to pipeline jurisdiction, the courts are unequal to the task of giving effect to the Constitution in a manner that establishes a relatively stable and predictable division of powers. In terms of constitutional theory, this statement represents a serious indictment of the judicial role in securing the legal underpinnings of Canada's system of government. At the very least, it demands careful scrutiny.

This article explores an alternative means of addressing uncertainty regarding pipeline jurisdiction. While acknowledging that the current legal principles are manifestly unsatisfactory, the argument presented here is that a workable interpretation of the transportation power can be developed through an analysis of the case law. By reformulating the guiding principles and tests, many of the leading pipeline cases - as well as analogous ones dealing with railways - can be seen to fall into discernible patterns. Furthermore, the proposed approach should, in most instances, significantly increase the degree of certainty with which results in future cases can be predicted.

The article is organized as follows. The next two sections describe the constitutional and jurisprudential contexts, beginning with a discussion of the transportation power and then turning to a review of the current approach to interpretation as set out in the cases. An alternative analysis of the transportation power as applied to pipelines is presented next, focusing first on "works" and then on "undertakings." Finally, a few comments are offered regarding jurisdiction over the NOVA pipeline system, a useful

Ibid. at 389.

Ibid.

Ibid. at 404-408.

Ibid. at 404. 
illustration of the strengths and remaining limitations of the proposed approach. While a political solution clearly remains an option worth considering for addressing uncertainty regarding the transportation power, the objective here is to set out the basis for a judicial resolution of this problem.

\section{THE TRANSPORTATION POWER}

The constitutional head of power at issue in the pipeline cases is s. 92(10)(a) of the Constitution Act, 1867:

92. In each Province the Legislature may exclusively make Laws in relation to Matters coming within the Classes of Subject next hereinafter enumerated; that is to say,-

10. Local Works and Undertakings other than such as are of the following Classes:-

(a) Lines of Steam or other Ships, Railways, Canals, Telegraphs and other Works and Undertakings connecting the Province with any other or others of the Provinces, or extending beyond the Limits of the Province;

This section applies to works and undertakings in the areas of transportation and communication, several of which are specifically enumerated and others, notably pipelines, are included within its scope by inference. "It operates in combination with s. 91(29), which brings within federal jurisdiction matters that are expressly excepted from provincial authority under s. 92. The result is federal jurisdiction over interprovincial and international (henceforth, extraprovincial) works and undertakings. The provinces retain jurisdiction over "local works and undertakings."

Several features of s. 92(10)(a) are notable when viewed from the perspective of the division of powers as a whole. It is a relatively narrow head of power, conferring jurisdiction only in the areas of transportation and communication. ${ }^{12}$ Although authority in these areas could have been determined under more general constitutional provisions, they are granted a special place in the division of powers by s. 92(10)(a).

The case law and legal literature contain little discussion of the purpose of s. 92(10)(a). This question has been touched on, however, by John Whyte in an article dealing with the federal "trade and commerce" power. In proposing a principled approach to constitutional adjudication, Whyte's point of departure is "a conception of the Canadian federal state that would support a federal, general economic power and

"I P.W. Hogg, Constitutional Law of Canada, 3d ed. (Toronto: Carswell, 1992) at 569, 582.

12 The application of this section to telecommunications, broadcasting, cable television, etc., is beyond the scope of this article. These topics are reviewed in Hogg, ibid. at 588-600. The distinction between the communications and transportation contexts was noted by Dickson C.J.C. in United Transportation Union v. Central Western Railway Corp., [1990] 3 S.C.R. 1112 at 1144 , 1146 [hereinafter Central Western]. See also Re National Energy Board Act, [1988] 2 F.C. 196 at 214 (F.C.A.) [hereinafter Cyanamid], where the analogy between broadcasting and pipelines was rejected. 
still leave provinces constitutional room to determine their own economic patterns."13 In his view:

That conception is expressed in the Constitution Act, 1867, and is based on that document's clear concern with nation building - with activities that produce a nation state that despite its illogicality in terms of geography, will function as a single state and as an economically viable whole. This view explains ... the special place of interconnecting (or nation-creating) transportation and communication systems created by s-ss. (a), (b) and (c) of s. 92(10). Economic survival and economic viability are implicit aims in the structure of the division of powers."

The singling out of transportation and communication in s. 92(10)(a) thus echoes themes that run throughout Canada's division of powers. ${ }^{15}$

If the purpose of s. 92(10)(a) is consistent with the overall constitutional structure of Canadian federalism, the interpretation of that section by the courts is distinctive in two notable ways. The first relates to the substance of legal reasoning and the second concerns the methodology of constitutional adjudication.

As a matter of substance, the lack of explicit attention to the delicate balance between federal and provincial roles within Canada's federal system is striking. ${ }^{16}$ In contrast with cases dealing with broadly-worded constitutional powers such as "peace, order and good government" rarely examine fundamental principles of federalism and their implications for determining which level of government is the most appropriate regulator for particular types of activities. Rather, they focus on parsing the cases and applying the established verbal formulae. A sophisticated theoretical framework for division of powers analysis has not emerged in the s. $92(10)(a)$ jurisprudence. ${ }^{19}$

The second notable feature of s. 92(10)(a) cases concerns the methodology for constitutional review. The standard approach to division of powers issues, as described

J.D. Whyte, "Constitutional Aspects of Economic Development Policy" in R. Simeon, Research Coordinator, Division of Powers and Public Policy (Toronto: University of Toronto Press, 1985) 29 at 44.

is See also C.H. McNaim, "Transportation, Communication and the Constitution: The Scope of Federal Jurisdiction" (1969) 47 Can. Bar Rev. 355 at 355. McNaim states that: "The maintenance of transport and communication facilities adequate to Canadian needs has historically been regarded as a vital factor in securing the economic and political viability of Canada as a federal union."

There may be limited exceptions to this generalization. As Whyte points out, the tensions surrounding this issue are evident in the judgments of Rand $J$. of the Supreme Court of Canada and Lord Parker of the Judicial Committee of the Privy Council in the Winner case, discussed infra. Whyte acknowledges, however, that "these notions were not explicitly developed by Lord Porter in his decision." See Whyte, supra note 13 at 31,64 (endnote 12).

18 See e.g. General Motors v. City National Leasing, [1989] I S.C.R. 641.

19 The contrast between the s. 92(10)(a) cases and those dealing with the "trade and commerce" power was noted by McNair, supra note 15 at 393. 
by Hogg, is comprised of the following two steps: (1) identification of the matter of the challenged law (characterization of the challenged law); and (2) assignment of the matter to one of the heads of legislative power (interpretation of the power-distributing provisions of the Constitution). ${ }^{20}$ These steps are, as Hogg notes, closely interrelated but nonetheless conceptually distinct. Since the constitutional division of powers establishes the limits of legislative authority, the focus on the law at issue is a logical first step. In determining whether legislative action is constitutionally valid, one begins by analyzing the purpose and effect of the legislative scheme and then turns to the question of which order of government has authority, under the Constitution, to enact legislation of that type.

The remarkable feature of the s. 92(10)(a) jurisprudence is that, by and large, it fails to follow this pattern and address these issues directly. It is not uncommon to find $s$. 92(10)(a) cases that make little or no reference to the legislative scheme which is, ultimately, at issue. Rather, the factual and legal analysis focuses on the particular characteristics of the work or undertaking in question. Thus, the jurisdiction of the NEB over a particular project is determined on the basis of the characteristics of the work or undertaking to be regulated, not through an analysis of the purpose and effect of the National Energy Board Act and a consideration of whether that type of legislative scheme fits within areas of federal competence as set out in the Constitution. ${ }^{21}$

These two characteristics of the s. 92(10)(a) case law reflect the manner in which the constitutional power is conferred. Rather than setting out a broad category of legislative authority (e.g., "trade and commerce" or "property and civil rights") and thereby directing attention to the legislative scheme at issue and its place within the overall division of powers, the section defines the jurisdictional matter in terms of the entity being regulated. Jurisdiction is therefore determined by whether the work or undertaking is intraprovincial or extraprovincial, not through an explicit evaluation of whether the legislative scheme is one that is more appropriately within federal or provincial authority.

Section 92(10)(a) thus invites, and perhaps requires, an approach to constitutional interpretation that is highly reductionist in both substance and methodology. The characterization of a work or undertaking as intraprovincial or extraprovincial is, in effect, a proxy for an explicit consideration of federalism values and for an examination of the applicable legislative scheme and its place within the division of powers. This reductionist and fact-based reasoning, combined with the highly variable and complex fact situations that may arise in the context of transportation facilities and operations, goes some way to explaining the apparent inability of the case law to provide a clear and generalizable analytical framework that is capable of producing predictable results in s. 92(10)(a) cases.

While this structural explanation of the jurisdictional uncertainty surrounding s. 92(10)(a) lends some support to Harrison's suggestion that recourse to judicial

See e.g. Westcoast, supra note 3; Cyanamid, supra note 12. 
interpretation should be foregone in favour of a political and administrative fix, the possibility that reductionist reasoning could yield satisfactory constitutional results should not be discounted altogether. There is no a priori reason why a principled and workable test for distinguishing interprovincial works and undertakings from their extraprovincial counterparts could not be developed. The interpretive challenge of $s$. 92(10)(a) is to formulate such a test, building where possible on the existing case law and reducing the current unacceptable level of indeterminacy. The interpretation of $s$. 92(10)(a) should, it is suggested:

(1) reflect the structure imposed by the wording of s. 92(10)(a) (i.e., the interprovincial or extraprovincial character of the work or undertaking is the determinant of jurisdiction);

(2) provide a satisfactory account of the case law, including any elements of the existing jurisprudence that are inconsistent with the proposed approach;

(3) establish a relatively certain basis for assigning jurisdiction under $\mathbf{s}$. 92(10)(a) in a wide range of fact situations (recognizing that there will always be anomalous factual contexts and hard cases); and

(4) yield results that are workable from a regulatory perspective and relatively consistent with the general purpose of s. 92(10)(a) and the fundamental federalism principles underlying Canada's division of powers.

The argument developed in this article is that the case law reveals an approach to interpreting s. 92(10)(a) that represents a significant advance over current practice when measured against these four criteria. To begin with, however, the legal analysis now employed by the courts is outlined and its deficiencies noted.

\section{THE "INTEGRAL" AND "ESSENTIAL" TESTS}

The most authoritative recent judicial statement on the interpretation of s. 92(10)(a) is the following passage from Central Western, a case concerning jurisdiction over a railway company operating within the province of Alberta. According to Dickson C.J.C.:

There are two ways in which Central Western may be found to fall within federal jurisdiction.... First, it may be seen as an interprovincial railway and therefore come under s. 92(10)(a) of the Constitution $A c t, 1867$ as a federal work or undertaking. Second, if the appellant can be properly viewed as integral to an existing federal work or undertaking it would be subject to federal jurisdiction under $s$. 92(10)(a). ${ }^{22}$ 
This description of the courts' approach indicates that s. 92(10)(a) establishes federal jurisdiction over two categories of works and undertakings: (1) those that are themselves extraprovincial; and (2) those that, while not extraprovincial, are integral to an extraprovincial work or undertaking.

The first category is generally seen as unproblematic. ${ }^{23}$ For example, the pipeline systems of TransCanada PipeLines Ltd. and Interprovincial Pipe Line Inc. are within this category, as are sausage-link pipelines crossing provincial or international boundaries. Similarly, transcontinental railways are clearly within federal jurisdiction under s. 92(10)(a). Federal jurisdiction over these national (or at least interprovincial) components of the country's transportation infrastructure is consistent with the nationbuilding objective described by Whyte. ${ }^{24}$ It also represents a constitutional response to the practical obstacles to effective regulation of these extraprovincial works and undertakings by the provinces.

The second category set out in the Central Western test, however, raises more interesting issues. Dickson C.J.C.'s description of this category indicates that otherwise intraprovincial works and undertakings can be brought within federal jurisdiction by operation of s. 92(10)(a). ${ }^{25}$ This explanation of the case law is supported by John Ballem, who summarizes the pipeline context as follows:

Certain facilities such as storage terminals, spur lines, injection facilities, and gathering lines may be situated entirely within the bounds of one province, yet connect in some fashion with a major transmission system. Such situations present the courts with the complex and often difficult question as to whether the connection or "nexus" is such as to cause the facilities to lose their local undertaking characterization and become a part of the federal undertaking and thus subject to the federal transportation power. ${ }^{26}$

The reading of this second category into s. 92(10)(a) is the product of a certain interpretive reach by the courts. As Hogg has noted: "The essential scheme of s. 92(10) is to divide legislative authority over transportation and communication on a territorial basis."27 When business operations or facilities are located entirely within a province, a finding of federal jurisdiction based on s. 92(10)(a) demands an explanation of the rationale for federal regulation. That explanation, according to the cases, is based on the relationship with the core federal work or undertaking. Whether this relationship leads to a finding of federal jurisdiction is determined using the "integral" or "essential"

J.B. Ballem, "Pipelines and the Federal Transportation Power" (1991) 29 Alta L. Rev. 617 at 619. A telecommunications case decided under this test that raises interesting issues is Alla. Govt. Tel. v. C.R.T.C., [1989] 5 W.W.R. 385 at 410 (S.C.C.) [hereinafter AGT]. The facts giving rise to this case can, however, be distinguished from the pipeline context. See S.A. Kennett, Pipeline Jurisdiction in Canada: The Case of NOVA Gas Transmission Ltd., CIRL Occasional Paper \#1 (Calgary: Canadian Institute of Resources Law, June 1996) at 26-29.

Supra note 13 at $44-45$.

See also Cyanamid, supra note 12 at 216.

Ballem, supra note 23 at $619-20$.

Hogg, supra note 11 at 566. 
tests. These tests give rise to the principal uncertainty regarding the transportation power.

The "integral" test is the broader of the two. It directs attention to a range of characteristics including ownership, control, operational integration, physical connection, and purpose. ${ }^{28}$ While no single factor is conclusive, the courts appear to group and weigh these characteristics to determine if the necessary "nexus" exists to bring the intraprovincial work or undertaking within federal jurisdiction.

The principal deficiency of this test is that the required type or extent of "nexus" is never spelled out in a formal manner that can be readily generalized across cases. As Dickson C.J.C. said in the Alberta Government Telephones (AGT) case:

It is impossible, in my view, to formulate in the abstract a single comprehensive test which will be useful in all of the cases involving s. 92(10)(a). The common theme in the cases is simply that the court must be guided by the particular facts in each situation. ${ }^{29}$

The statement that cases must be decided on their facts is, of course, virtually tautological. The problem with the fact-based approach described by Dickson C.J.C., however, is that the indeterminacy of the applicable principles and indicia makes it difficult to organize or weigh "facts," particularly those pointing towards different conclusions. The cases demonstrate that there are numerous ways that works or undertakings may be related, and that these relationships may be characterized. Consequently, it is often difficult to predict in advance how any particular fact situation will be decided. The result is a high level of jurisdictional uncertainty that, as noted by Harrison, ${ }^{30}$ can be resolved only through facility-by-facility litigation.

Recognition of this problem is not new. In a review of the transportation and communication powers published in 1969, Colin McNairn noted that the determination of when an intraprovincial work or undertaking is so closely related to an extraprovincial one that it will be found to be within federal jurisdiction is hampered by "the persisting problem that the authorities are not clear, except in some very specific instances, of the required degree or aspects of integration." ${ }^{31}$

The implications of this problem were also discussed by I.H. Fraser in a 1984 article. Noting that "the distinction between intra- and inter-provincial works or undertakings has long been an important focus of attention" of courts and commentators, he concluded that:

A frequently cited enumeration of these indicia is Re Westspur Pipe Line Co. Gathering System (1957), 76 C.R.T.C. 158 at 177-78 (Board of Transport Commissioners); see also Ballem, supra note 23 at $620-21$.

29 
Despite this, the cases in this area are, taken as a group, the most unsatisfactory of any in Canadian constitutional law. No attempt will be made here to reconcile all these cases on their own terms: the various dicta are simply too confused, confusing and contradictory to be harmonized in any global sense. ${ }^{32}$

In response to the indeterminacy of the "integral" test, a more precise means of evaluating the relationship between intraprovincial and core federal works and undertakings has been proposed. ${ }^{33}$ The clearest judicial statement of this approach is by MacGuigan J.A. in Re National Energy Board Act (the Cyanamid reference), a case dealing with pipeline jurisdiction. After a selective review of the case law, MacGuigan J.A. stated that:

Rather than trying to pick and choose among analogies, I believe a far sounder approach is to seek governing principles. In this context it is immediately apparent that in the vast majority of cases under paragraph 92(10)(a) the courts have explicitly required the parties alleging federal jurisdiction to meet what the NEB initially termed the "vital, essential or integral to the undertaking" test, and then shortened to the "essential test". ${ }^{34}$

The "essential" test is interpreted to mean that an intraprovincial work or undertaking is within federal jurisdiction under s. 92(10)(a) if it is essential to the operation of an extraprovincial work or undertaking. The dependence of the latter on the former establishes the "necessary nexus,"

The "essential" test appears, at first glance, to offer the prospect of greater certainty. In a 1991 article, Ballem argued that: "With the emergence of the 'essential' test as the governing principle, one should be able to examine certain aspects of pipeline operations in Canada and predict their jurisdictional fate with some level of confidence."36 This prediction, as noted by Harrison, has proven to be overly optimistic. ${ }^{37}$ Pipelines continue to provide fertile ground for litigation. There are three possible explanations for this fact.

First, although a number of authorities can be cited to support the "essential" test, ${ }^{38}$ there is evidence that it has not entirely supplanted the broader "integral" test. For example, in the Central Western case Dickson C.J.C. reviewed several indicia and concluded that: "Finally, and perhaps most importantly, it cannot be said that $\mathrm{CN}$ [Canadian National Railway] is in any way dependent on the services of the appellant."39 The "essential" test, while a key component in the "integral" analysis, was not the only criterion considered to be relevant. Wilson J.'s dissenting opinion in

I.H. Fraser, "Some Comments on Subsection 92(10) of the Constitution Act, 1867" (1984) 29 McGill L.J. 557 at 594.

See Ballem, supra note 23 at 623-27.

Cyanamid, supra note 12 at 216.

Ibid.

Ballem, supra note 23 at 627.

Supra note 5 at 391.

Cyanamid, supra note 12 at 216.

Central Western, supra note 12 at 1142. 
Central Western argued specifically that "the authorities do not reveal that dependency of federal enterprises on 'subsidiary' provincial operations is the bench mark of federal jurisdiction. ${ }^{240}$

Second, the "essential" test does not provide an answer to the critically important prior question: what facilities or operations are at issue? This question arises in the determination of whether certain activities constitute one or more works or undertakings. If it is concluded that there is more than one work or undertaking, one must then determine which intraprovincial activities or facilities constitute the work or undertaking to which the "essential" test is applied. Answering these questions may be difficult given the inherent functional interrelationships between pipeline systems. For example, it is clear that a sausage-link connection or an interprovincial mainline cannot operate without upstream and downstream connecting facilities. In principle, some such facilities must therefore be "essential" to the interprovincial pipeline. The practical determination of which particular works or undertakings - e.g., individual pipelines, pipeline systems, related facilities, etc. - satisfy the "essential" test and should therefore be brought within federal jurisdiction is, however, far from self-evident in many instances. ${ }^{41}$ Moreover, the hoped-for predictability in s. 92(10)(a) jurisprudence is arguably impeded by conceptual confusion regarding the distinction between works and undertakings. This distinction provides the starting point for the interpretation of $s$. 92(10)(a) discussed below.

Finally, the "essential" test may yield results that are, in certain instances, too centralizing for the courts to accept. There are dicta in the s. 92(10)(a) cases that reveal a reluctance to accept reasoning that would, as stated by Dickson C.J.C. in Central Western, "undermine completely the division of powers." 42 As transportation and communication activities become increasingly interconnected, there may be many instances where intraprovincial gathering or distribution systems are arguably essential to extraprovincial works and undertakings. Sweeping all of these intraprovincial facilities and operations into federal jurisdiction, however, might leave very little of a "local" nature within provincial jurisdiction. It is possible, therefore, that a concern with the appropriate federal-provincial balance may underlie a reluctance of the courts to rely exclusively on the "essential" test.

The explanation may be debated, but the end result is unquestionable. The "essential" test has not succeeded in resolving the indeterminacy that has plagued the "integral" analysis. While the legal principles may well be settled, they are hardly satisfactory. A new approach is therefore required if a judicial solution to jurisdictional uncertainty is to be found. The following sections present such an approach. The argument is that a structure can be observed in the s. 92(10)(a) cases which provides a more coherent and economical approach than the two-stage test described in Central Western. Although

lbid. at 1149.

This issue is illustrated by the NEB's Altamont decision, discussed in Kennett, supra note 23 at 14-15.

Central Western, supra note 12 at 1146. 
this new approach has not been articulated by the courts, they have been remarkably faithful to it in interpreting and applying the transportation power.

\section{WORKS AND UNDERTAKINGS}

The distinction between works and undertakings is proposed as the starting point for interpreting and applying s. 92(10)(a). This distinction has, in practice, been frequently overlooked or obscured in the case law. ${ }^{43}$ When it is addressed directly, however, the cases indicate that these terms are to be read disjunctively, with "work" referring to a "physical thing" 44 and an "undertaking" being "not a physical thing, but ... an arrangement under which ... physical things are used." 45

The importance of this distinction has been noted in previous commentary on $\mathbf{s}$. 92(10)(a). ${ }^{46}$ It has not been dealt with in a definitive way in the case law, although the argument that works and undertakings should be treated separately for purposes of $\mathbf{s}$. 92(10)(a) is supported by a number of dicta that are reviewed below.

\section{JURISDICTION OVER WORKS}

\section{A. OVERVIEW}

The proposed application of s. 92(10)(a) to works can be defined in a relatively narrow and precise manner. Following the structure of the section, intraprovincial and extraprovincial works must be distinguished. The argument here is that the best approach is a simple one. Intraprovincial works are works - that is, physical things located entirely within the boundaries of a province. Extraprovincial works cross provincial or international boundaries. In contrast with the Central Western approach, it is argued that there is no basis for sweeping intraprovincial works into federal jurisdiction by virtue of their relationship to extraprovincial ones.

As applied to pipelines, this distinction yields the following results. Intraprovincial works include segments of pipeline (and related facilities) that begin and end within a single province. Extraprovincial works are transboundary pipeline segments that provide the physical connection between intraprovincial works and works in another province or in the United States. These extraprovincial works may include sausage-link connections, providing transborder links, or larger interprovincial networks.

\section{B. THE CASE LAW}

This interpretation of s. 92(10)(a) as it applies to works finds considerable support in both results and dicta in the case law. A prime example of its congruence with the results of s. 92(10)(a) cases, if not with their explicit reasoning, is the decision in 
Kootenay Railway. ${ }^{47}$ This case concerned a plan to construct a railway line in British Columbia to a point one-quarter of an inch from the international border. This line was to connect with another line, constructed by an American company, which stopped just on the other side of the border.

The Supreme Court of Canada, in a split decision, found in favour of provincial jurisdiction. Martland J. summarized the majority opinion as follows:

[A] provincial Legislature can authorize the construction of a railway line wholly situate within its provincial boundaries. The fact that such a railway may subsequently, by reason of its interconnection with another railway and its operation, become subject to federal regulation does not affect the power of the provincial Legislature to create it. ${ }^{48}$

The key distinction implicit in this passage is arguably between "railway line" and "railway.", The former is a work; the latter an undertaking. While the work is entirely intraprovincial, it may be used by an extraprovincial railway undertaking.

Ballem characterized this decision as "seemingly anomalous" and stated that it "rather unexpectedly upheld provincial jurisdiction, although on very narrow grounds." planned for the transfer of railway traffic along the combined lines. He also quoted from the dissent of Hall J., who stated that:

There never was the slightest intention on the part of those furthering the project that Kootenay would be a wholly contained provincial undertaking with an operation beginning and ending within British Columbia. It was conceived and intended as part and parcel of an international undertaking .... Throughout the argument the unreality of the whole situation became crystal clear that the Court was being called upon to deal with a wholly fictitious situation dressed up in legalistic terminology and argument involving corporate powers to obscure the realities of what was being proposed."

Hall J.'s focus is clearly on the extraprovincial undertaking that would emerge once the line was put into operation.

The disagreement between majority and minority opinions might thus be characterized as turning on confusion about whether the case concerned a work or an undertaking. The majority arguably treated the principal issue as jurisdiction over the construction of a physical work. The above-quoted passage from Hall J.'s dissent, however, clearly refers to the "undertaking" and its operations. The failure to agree on

47 Kootenay and Elk Railway Co. v. Canadian Pacific Railway Co. (1972), 28 D.L.R. (3d) 385 (S.C.C.) [hereinafter Kootenay Railway].

48 lbid. at 405-406.

49 Fraser, supra note 32 at 583 observes that the term "railway" can be used in two ways: "(i) railway works - that is to say, tracks, rolling stock and other equipment; or (ii) railway undertakings - that is to say, the entities which own, operate or make use of these works."

so Ballem, supra note 23 at 629.

st Kootenay Railway, supra note 47 at $416-17$. 
this fundamental issue may explain how two options, each persuasive in its own terms, yielded diametrically opposite jurisdictional conclusions.

Clarification of the distinction between works and undertakings suggests that the Kootenay Railway case should be understood as deciding jurisdiction over the work the railway line stopping just short of the border. Authority over works implies authority to regulate their construction, since that is how these "physical things" are brought into being. The operation of that work, in other words its eventual use by an undertaking, was therefore not relevant. As the majority noted, however, the jurisdictional answer may change once a work is brought into operation and the entity being regulated is an undertaking.

The majority opinion - including its comments regarding the eventual emergence of an extraprovincial undertaking - is thus consistent with the approach to works under s. 92(10)(a) that is proposed in this article. Applying the analysis proposed here to the facts in Kootenay Railway makes the decision appear less anomalous and the reasoning less contrived. It also explains how the minority, by asking a different question, arrived at a different jurisdictional outcome.

Fulton v. Energy Resources Conservation Board ${ }^{52}$ is another decision that may appear to be somewhat anomalous on the conventional interpretation of s. 92(10)(a). ${ }^{{ }^{3}}$ It too can be explained, at least in part, using the proposed approach to works. In this case, the Supreme Court of Canada upheld the authority of Alberta's Energy Resources Conservation Board, the predecessor of the Energy and Utilities Board, to authorize the construction and operation of an electrical transmission line that was to extend from Langdon, Alberta to a point just on the Alberta side of the Alberta-British Columbia border.

Laskin C.J.C.'s judgment did not deal with the distinction between works and undertakings in a clear and consistent manner. He also relied in part on the absence of federal legislation in upholding provincial jurisdiction to regulate the construction of the intraprovincial facilities and to authorize, but not regulate, the interprovincial connection. ${ }^{54}$ These factors complicate a comprehensive analysis of his reasoning.

On the specific issue of the construction of the transmission line as a "work," however, the decision in Fulton is clearly intelligible on the theory advanced here. As with the railway line in Kootenay Railway, the proposed transmission line was to be a physical thing constructed entirely within Alberta. Consequently, it was an intraprovincial work, coming within provincial jurisdiction. ${ }^{\text {ss }}$ The result in Fulton is also defensible on the very practical basis that, as Whyte observes, "the regulatory

32 [1981] I S.C.R. 153 [hereinafter Fulton].

53 Ballem, supra note 23 at 629-30.

s4 Fulton, supra note 52 at 161-62.

ss Laskin C.J.C. states that: "the proposed works in Alberta may properly be regarded as local works for the purposes of the application that was before the Energy Resources Conservation Board" (ibid. at 166). 
objective of the province (controlling the location of high voltage transmission lines) is patently desirable and is highly suitable for provincial regulation." 56 Whether or not the interprovincial operation of that line is a federal matter under s. 92(10)(a) should be decided according to principles applicable to undertakings, a subject addressed below.

Dicta in the Cyanamid case also provide judicial support for the proposed approach to works. At issue was jurisdiction over a "bypass" pipeline that was to provide a direct link between the TransCanada PipeLines Ltd. (TCPL) mainline with an industrial customer, thereby avoiding the local distribution company that had previously supplied the customer. The entire bypass pipeline was to be within Ontario. MacGuigan J.A. of the Federal Court of Appeal stated that:

As a work, the proposed pipeline exists solely within the province of Ontario and, as established by the B.C. Electric Railway case, ... mere physical connection to the admittedly interprovincial TCPL work is not sufficient to found federal jurisdiction. If it is to come under 92(10)(a), I believe it must therefore be as an undertaking rather than as a work alone. ${ }^{37}$

This passage affirms that a separate analysis of works and undertakings is required under s. 92(10)(a). Furthermore, MacGuigan J.A.'s reasoning supports the argument that a pipeline or other "physical thing" that does not itself cross a provincial or international boundary cannot be an extraprovincial work under s. 92(10)(a). Physical connection between the bypass and mainline pipelines, with the functional and operational relationship that inevitably results, was not sufficient to bring the bypass line under federal jurisdiction.

The proposed approach is also supported by the 1996 decision of the Federal Court of Appeal in the Consumers' Gas case. ${ }^{58}$ The issue was whether the Ottawa East Line, a component of the local distribution network owned and operated by Consumers' Gas Company Ltd., was a federal work or undertaking by virtue of the fact that it supplies gas to - and is therefore essential to - the interprovincial Niagara Line. The National Energy Board had found in favour of federal jurisdiction over the Ottawa East Line. ${ }^{59}$ In reversing this decision on appeal, the Court explained its approach to this issue as follows:

In the first place, and at the most basic level, there is simply no ground for the Board's finding, which is implicit and not even discussed in the reasons of the majority, that the Ottawa East Line constitutes a separate undertaking for constitutional purposes. There is no question, of course, that the line is a work, a physical thing, but as such it is wholly within the limits of Ontario and the simple fact of its physical connection to an interprovincial work, the Niagara Line, does not give it a federal character. As an undertaking, the Ottawa East Line simply has no separate existence. ${ }^{\infty}$

\footnotetext{
\$6 Whyte, supra note 13 at 57.

57 Cyanamid, supra note 12 at 219.

so Supra note 3.

s9 $\quad$ Niagara Gas, supra note 2.

6o Consumers' Gas, supra note 3 at $152-53$ (para. 6).
} 
This passage again underlines the importance of distinguishing between works and undertakings when applying s. 92(10)(a). As in Cyanamid, the court stated that an intraprovincial work cannot be brought under federal jurisdiction simply by virtue of its connection with an extraprovincial one. Furthermore, while a segment of pipeline is itself a work, it is not necessarily a free-standing undertaking. An undertaking - the arrangement by which the work is used - is something more than simply a work in use.

\section{WORKS AND THE "NEXUS" APPROACH}

The clear implication of the cases reviewed above is that, when dealing with works, the second test enunciated in Central Western should not be applied. In particular, works located within a province cannot become subject to federal jurisdiction simply by virtue of interconnection with an extraprovincial work.

The inductive route to this conclusion, based on the case law discussed above, is complemented by deductive reasoning. The second test in Central Western requires a means of determining whether the nexus between extraprovincial and intraprovincial works is sufficient to sweep the latter into federal jurisdiction. The two most obvious indicia of interconnectedness are physical connection and operational or functional integration. However, each of these approaches is inconsistent with either the constitutional division of powers explicitly envisaged by s. 92(10)(a) or the conceptual distinction between works and undertakings.

The problem with a physical connection test for works is that, in the case of transportation facilities, it effectively eliminates provincial jurisdiction over local works. As noted by Dickson C.J.C. in the Central Western case:

Railways, by their nature, form a network across provincial and national boundaries. As a consequence, purely local railways may very well "touch", either directly or indirectly, upon a federally regulated work or undertaking. That fact alone, however, cannot reasonably be sufficient to tum the local railway into an interprovincial work or undertaking within the meaning of s. 92(10)(a) of the Constitution Act, 1867. Furthermore, if the physical connection between rail lines were a sufficient basis for federal jurisdiction, it would be difficult to envision a rail line that could be provincial in nature: most rail lines located within a province do connect eventually with interprovincial lines. ${ }^{61}$

In the words of Fraser:

physical connection cannot be the sole focus of analysis where paragraph [92(10)](a) works are concerned: few driveways in the nation would escape federal regulation on that basis. ${ }^{62}$

The situation with pipelines is identical. A physical connection test would have the effect of reading provincial jurisdiction over "local works" out of s. 92(10). Not surprisingly, as shown in the passages from the Cyanamid and Consumers' Gas cases

62 Fraser, supra note 32 at 606 ; see also McNaim, supra note 15 at 386-87. 
quoted above, ${ }^{63}$ the courts have consistently rejected physical connection as determinative of jurisdiction. ${ }^{64}$

The alternative test, based on operational or functional integration, also has the potential to erode provincial jurisdiction over local works. Since operation coordination is necessary for physically connected works such as pipelines, this test is vulnerable to the same division of powers critique as the physical connection test. Even if narrowed to the "essential" test, determining what upstream facilities should be swept into federal jurisdiction is problematic. In the case of a gathering system feeding a sausage-link pipeline or an extraprovincial mainline, for example, can certain upstream components be isolated as "essential," or is the entire system of works in some sense essential to the extraprovincial line? ${ }^{65}$

There is, however, a further fundamental objection to a test based on operational connection. Reliance on this criterion to determine jurisdiction over works is inconsistent with the distinction between works and undertakings that, it is suggested, is central to the interpretation of s. 92(10)(a). The operational connection between works relates to the way that these "physical things" are used. In other words, it is relevant to the identification of undertakings, not physical works. As Fraser has argued, the distinction between works and undertakings leads to the conclusion that:

A work that does not physically extend beyond the limits of a province is not an inter-provincial work, no matter how intimate a functional connection it may have with other works in other provinces. ${ }^{.6}$

The nature of the operational relationship, as noted by the majority in the Kootenay Railway case, should be taken into account when determining jurisdiction over the undertaking which makes use of the works. It is therefore part of a separate line of analysis for purposes of interpreting s. 92(10)(a).

\section{DETERMINING WHAT CONSTITUTES A WORK}

One implication of this approach is that regulators and the courts should take works as they find them when applying s. 92(10)(a). In other words, works should be accepted by the regulator as they are conceived by the proponent. The result is that an extraprovincial work could be anything from a very small sausage-link segment to a single pipeline extending from Alberta to Ontario.

It may appear, initially at least, somewhat arbitrary to leave this much flexibility in the definition of works to proponents. Furthermore, proponents will have a measure of flexibility to design the components of their pipelines in order to achieve desired

Supra note 12 at 219 ; note 3 at $152-53$ (para. 6).

4 See also Montreal, supra note 44 (see Hogg, supra note 11 at 345-46); Central Western, supra note 12 at $1128-30$. 
jurisdictional outcomes. There are two reasons, however, why this situation should not cause concern.

First, the problem of determining what constitutes an individual intraprovincial or extraprovincial work is unavoidable given that s. 92(10)(a) specifically identifies works as a matter for jurisdictional purposes. Having ruled out physical and operational discontinuities as the basis for drawing the line, one has little choice but to fall back on a project-based definition of what constitutes a work. Since there is considerable variation in the configuration of pipeline systems and the physical extent of individual components, a degree of arbitrariness in defining works is inevitable. An approach should therefore be adopted that offers certainty in individual cases and makes practical sense. Taking the proponent's conception of the project as the basis for differentiating intraprovincial and extraprovincial works will yield a concrete and clearly defined work. It also has the practical advantage of matching the regulatory regime that follows from the jurisdictional decision with the project as planned and executed by the proponent.

The second reason why it is acceptable to take works as presented by the proponent is that the application of s. 92(10)(a) is not the end of the jurisdictional story. A separate analysis is necessary to determine which order of government has authority over the relevant undertakings. In addition, works and undertakings may be subject to regulation based on other constitutional heads of power. A relatively restrictive approach to works under s. 92(10)(a) does not, therefore, unduly short-circuit constitutional analysis. It simply provides a logical and practical means of distinguishing between extraprovincial and intraprovincial works, as required by $s$. 92(10)(a).

\section{E. EXTRAPROVINCIAL UNDERTAKINGS AND WORKS}

This broader jurisdictional analysis raises an interesting issue in the event that an undertaking constructs an intraprovincial pipeline segment as an addition to its extraprovincial mainline system. Subject to application of the doctrine of colourability, it is suggested that this pipeline segment has a constitutional double aspect. Applying the project-based definition of works, the pipeline segment is a physical thing located entirely within a province and is consequently subject to provincial jurisdiction. It will be recalled, however, that undertakings are arrangements by which works are used. As the discussion below will show, jurisdiction over an undertaking brings with it authority over the operation as a whole, including the undertaking's construction and operation of its works. The intraprovincial component of an extraprovincial pipeline system therefore has a federal aspect; it can be regulated federally as a function of jurisdiction over the undertaking.

Assuming that there is applicable federal legislation, the doctrine of paramountcy would give priority to federal regulation of the pipeline segment. Furthermore, it will generally make most sense for the proponent to submit to the federal regulatory process from project initiation through to the pipeline segment's operation as part of the extraprovincial undertaking. Nonetheless, the double aspect doctrine suggests that, in the absence of a federal regulatory scheme, the province could regulate the construction 
(but not the operation) of an intraprovincial pipeline segment that is built by an extraprovincial undertaking. ${ }^{67}$

\section{F. SUMMARY AND EVALUATION}

To summarize, the approach outlined here applies s. 92(10)(a) to works in two relatively straightforward steps. The first - identification of the work - is accomplished by taking the work as conceived by the proponent. The second step is to determine whether the "physical thing" at issue is located within a province or extends across a provincial or international boundary. Jurisdiction depends on the answer at the second step.

How does this approach to works measure up against the four criteria for judicial interpretation of s. 92(10)(a) that were proposed earlier in the article? First, it corresponds well with the "essential scheme" of s. 92(10)(a) which, as noted above, divides legislative authority over transportation and communication on a territorial basis according to the nature of the work or undertaking at issue. ${ }^{68}$ The jurisdictional decision depends on whether the work in question is intraprovincial or extraprovincial. In addition, the proposed approach is consistent with the conceptual distinction between works and undertakings in that it does not rely on the operational considerations implicit in the "integral" and "essential" tests.

Second, to the extent that the courts have paid attention to the distinction between works and undertakings, this approach is consistent with the s. 92(10)(a) cases. In particular, the Kootenay Railway and Fulton cases are intelligible in terms of this approach and it is supported by dicta in both Cyanamid and Consumers' Gas.

Third, it provides a relatively certain basis for assigning jurisdiction over works. A given work is defined in the first step in accordance with the proponent's project. The answer to the second step depends simply on whether the work in question crosses a provincial or international boundary. Abandonment of the second test in Central Western would eliminate the principal source of uncertainty, since intraprovincial works could no longer be swept into federal jurisdiction by virtue of their relationship, however defined, with extraprovincial ones.

Finally, it yields results that are workable from a regulatory perspective and are consistent with the fundamental federalism principles underlying Canada's division of powers. It avoids the slippery slope of expanding federal jurisdiction to include all intraprovincial works, while filling a potential regulatory gap by establishing federal authority over works that physically cross provincial boundaries and consequently

This analysis may shed further light on the decision in Fulton, supra note 52. As noted above, one of the reasons for upholding provincial jurisdiction to authorize construction of the transmission line was the absence of a federal regulatory regime governing that situation. It should be noted, however, that the proponent in Fulton was an intraprovincial undertaking, not an extraprovincial one. 
cannot be regulated in their entirety by a provincial legislature. In this respect, it is consistent with a clear constitutional rationale for federal authority over certain types of physical structures. As with the "gap" branch of the federal "peace, order, and good government" power, ${ }^{69}$ the Constitution allocates power to Parliament over matters that cannot be regulated effectively by the provinces.

\section{JURISDICTION OVER UNDERTAKINGS}

\section{A. OVERVIEW}

The proposed application of s. 92(10)(a) to undertakings involves a two step process that parallels the approach outlined above for works. The first step is to identify the undertaking. Second, the undertaking is characterized as either intraprovincial or extraprovincial. The jurisdictional issue is resolved on the basis of the answer at the second step.

The approach is intended to avoid the indeterminacy of the Central Western interpretation. That indeterminacy, as noted above, is rooted in the focus of the second test in Central Western on the relationships between separate intraprovincial and extraprovincial undertakings, as evaluated using the "integral" and "essential" tests. Given the potential variation in the means of organizing pipeline activities and the interrelationships between them, any recourse to these tests is bound to lead into a morass of fact-specific litigation.

The alternative developed here is to abandon the second branch of the Central Western approach - as was proposed above for works - and base the application of s. 92(10)(a) instead on a relatively precise definition of what constitutes an undertaking and clear criteria for distinguishing intraprovincial undertakings from extraprovincial ones. It will be shown that this approach provides not only a logical and workable means of interpreting s. 92(10)(a), but also yields results that are generally consistent with the case law.

The definition of "undertaking" is thus the cornerstone of the proposed approach. The starting point in addressing this issue is the distinction between works and undertakings. Undertakings, it will be recalled, are the arrangements through which works are used. ${ }^{70}$ The Consumers' Gas case makes clear, however, that an undertaking is not simply a work in use. "Rather, as Hogg has noted, the courts use "undertaking" in a manner equivalent to "organization" or "enterprise." ${ }^{72}$ The clearest analogy is arguably with a business.

A review of the s. 92(10)(a) case law indicates that there are three defining characteristics required for activities to constitute a single undertaking: unity of 
ownership, unity of direction (i.e., purpose), and unity of control (i.e., management and operational coordination). These characteristics are the principal indicia that have been used by the courts when deciding if the activities at issue are part of a single undertaking for purposes of s. 92(10)(a). ${ }^{73}$ In addition, they are among the criteria relied on in applying the "integral" test to determine if the relationship between extraprovincial and interprovincial undertakings is sufficiently close to sweep the latter into federal jurisdiction. ${ }^{74}$ In fact, the similarity in indicia and analysis used by the courts when applying the two branches of the Central Western approach is striking. For example, Dickson C.J.C.'s judgment in Central Western underlines the importance of "operational connection" as both a criterion for determining whether a single undertaking exists ${ }^{75}$ and a measure of the integration between separate undertakings when applying the "integral" test. ${ }^{76}$

Reference to these characteristics thus builds on well-established elements of the case law. To address the indeterminacy of the current approach, however, a reevaluation of the purpose which these indicia should serve is necessary. Rather than forming a menu of attributes, some aggregation of which leads to a conclusion in favour of federal or provincial jurisdiction, the argument here is that they can be fashioned into a relatively bright line test for identifying undertakings.

The proposed approach is that the three-fold unity of ownership, direction and control (the "three unities") should be viewed as the sine qua non of an "undertaking" for purposes of s. $92(10)(a)$. Where one or more of these characteristics is missing, a single undertaking does not exist.

Once the undertaking is identified, the second step in the s. 92(10)(a) analysis is to determine whether it is intraprovincial or extraprovincial. In most instances, this determination will not be particularly complicated. If an undertaking has physical facilities or business operations that extend extraprovincially, or if its business involves the transportation of goods or people across provincial or international boundaries, then it is extraprovincial and within federal jurisdiction. The presence of "continuous and regular" extraprovincial operations, even if only constituting a small percentage of the undertaking's activities, will result in the entire undertaking being treated as extraprovincial. ${ }^{77}$ However, if the undertaking's facilities, staff and business operations are contained within the boundaries of a single province or if extraprovincial activities are casual or occasional, it is an intraprovincial undertaking coming under provincial jurisdiction.

Westcoast, supra note 3 at 291-96 (paras. 31-34).

Hogg, supra note 11 at 575-79.

Central Western, supra note 12 at 1136.

Ibid. at 1137.

Re Ottawa-Carleton Regional Transit Commission and Amalgamated Transit Union, Local 279 (1983), 44 O.R. (2d) 560 at 569. 


\section{B. THE WINNER ANALYSIS AND IDENTIFICATION OF THE UNDERTAKING}

The focus of the proposed approach on the identification of the undertaking at issue has its jurisprudential roots in the leading s. 92(10)(a) case of Ontario (AttorneyGeneral) v. Winner. ${ }^{78}$ This case involved a bus line that transported passengers from Boston to Nova Scotia via New Brunswick. The jurisdictional issue was whether the New Brunswick Motor Carrier Board had authority to prohibit the bus line from picking up and putting down passengers at various points within the province. The Supreme Court of Canada held that the province could regulate journeys that began and ended within New Brunswick on the grounds that Winner was engaged in two enterprises, one intraprovincial and the other extraprovincial. ${ }^{79}$ Since the intraprovincial undertaking was not essential to the extraprovincial one, it could be separated for constitutional purposes and regulated by the province.

This decision was overturned by the Judicial Committee of the Privy Council. The Privy Council rejected the dual enterprise analysis, stating that:

This method of approach results from a misapprehension of the true construction of s. 92(10)(a).... The question is not what portions of the undertaking can be stripped from it without interfering with the activity altogether: it is rather what is the undertaking which is in fact being carried on. Is there one undertaking, and as part of that one undertaking does the respondent carry passengers between two points both within the Province, or are there two?

Although the services provided differed in the sense that some journeys began and ended within a single province and others crossed provincial or international boundaries, the Privy Council found that "it was the same undertaking which was engaged in both activities." ${ }^{81}$ According to Lord Porter:

The undertaking in question is in fact one and indivisible. It is true that it might have been carried on differently and might have been limited to activities within or without the Province, but it is not, and their Lordships do not agree that the fact that it might be carried on otherwise than it is makes it or any part of it any the less an interconnecting undertaking. ${ }^{82}$

Two key points should be noted. First, Winner supports the argument that the first question to be asked when applying s. 92(10)(a) to undertakings is the following: What is the undertaking which is in fact being carried on? Second, Winner indicates that undertakings should be taken as they exist, not as they might be configured under different arrangements. 


\section{THE CASE LAW}

The proposed approach is thus consistent with the basic analysis set out in Winner. It clearly differs, however, from the tests articulated in Central Western. In particular, it does not allow for otherwise "intraprovincial" undertakings to be brought under federal jurisdiction by virtue of an "integral" or "essential" relationship with a federal undertaking. Despite dropping the second branch of the Central Western approach, the proposed analysis yields results that are consistent with the results in many of the s. 92(10)(a) cases. On the basis of this consistency, it can be argued that this interpretation is not simply a new and simplified test; it incorporates and gives explicit expression to the motivating factors that appear to be guiding many of the decisions in s. 92(10)(a) cases. The pattern that it reveals, although not explicitly articulated by the courts, is nonetheless evident once the case law is examined from this perspective. In many instances, it reaches the same result by a clearer and more direct legal analysis.

This high degree of congruence can be demonstrated by examining examples from two categories of cases. The first category consists of cases that have found in favour of federal jurisdiction: Flamborough, ${ }^{83}$ Dome, $^{84}$ and Westcoast. ${ }^{85}$ In the second category are cases where undertakings came within provincial jurisdiction: Central Western, ${ }^{86}$ Cyanamid, $^{87}$ and Consumers' Gas. $^{88}$

\section{Cases Upholding Federal Jurisdiction}

The Flamborough case is an important pipeline decision that concluded in favour of federal jurisdiction under s. 92(10)(a). This case began as an application by Interprovincial Pipe Line Inc. (IPL) to the NEB for approval of proposed modifications to its No. 8 pipeline in Ontario in order to make that line suitable for transporting specification propane. ${ }^{89}$ The NEB approved the application, but the decision was challenged by the Township of Flamborough. Flamborough argued that, following the conversion, the character of the line would change and it should therefore be severed, for constitutional purposes, from the IPL system and viewed instead as an intraprovincial work or undertaking coming within provincial jurisdiction.

The Federal Court of Appeal rejected this argument on the grounds that the specification propane, that was obtained through the removal of certain substances from natural gas liquids, was essentially the same substance that was transported by the other IPL lines. ${ }^{90}$ The court was also satisfied that the "modified line No. 8 is an integral part of the system operated by Interprovincial and that the system is one undertaking

Flamborough (Tounship) v. National Energy Board (1984), 55 N.R. 95 (F.C.A.) [hereinafter Flamborough]; leave to appeal to the Supreme Court of Canada refused (1984), 58 N.R. 79.

a Dome Petroleum Lid. v. National Energy Board (1987), 73 N.R. 135 (F.C.A.) [hereinafter Dome].

ss Supra note 3.

*. Supra note 12.

$7 \quad$ lbid.

Supra note 3.

99 Flamborough, supra note 83 at 97 (para. 8).

olbid. at 103 (para. 41). 
from which modified line No. 8 is not to be severed."91 This result can easily be explained by the approach to undertakings proposed here. The No. 8 pipeline continued to be owned and operated by IPL after the modifications and it continued to serve the same general purpose as the IPL system as a whole. Unity of ownership, direction and control were thus present, confirming the common-sense observation that the modified pipeline remained unquestionably a part of the IPL business enterprise. The undertaking in question was therefore IPL, which is an extraprovincial business. The finding of federal jurisdiction follows directly.

The Dome case is a second relevant example. The issue was whether the NEB had erred in asserting jurisdiction over underground storage caverns connected to the extraprovincial Cochlin pipeline system. Mahoney J.A. noted that the pipeline system and the caverns had common ownership, although he stated that this fact was not determinative. ${ }^{92}$ The core of his judgment is the finding that the caverns were "essential" to the extraprovincial system and therefore were subject to federal jurisdiction. He stated that:

The terminalling facilities of a pipeline, whoever provides them and whatever the ultimate destination of shipments, are provided solely for the benefit of shippers on the line. In my opinion, when they are provided by the owner of the transportation undertaking, they are part and parcel of that undertaking. That is the case here. The joint venture's storage caverns are an integral and essential part of its Cochlin system. ${ }^{93}$

As with Flamborough, this case can be characterized as one where the court found that the facilities in question were part of a single undertaking on the basis of common ownership, operational integration, and common purpose. Since that undertaking is extraprovincial, it comes within federal jurisdiction.

Finally, the Federal Court of Appeal's recent decision in the Westcoast case is particularly significant for the argument advanced here. This decision concerned the pipelines and related facilities of Westcoast Energy Inc. in British Columbia ${ }^{94}$ The court applied the first test in Central Western, characterizing the issue as whether Westcoast was involved in one undertaking or two. After reviewing in detail the factual evidence regarding Westcoast's operations, the Court held that Westcoast's gathering system was not a separate local undertaking for s. 92(10)(a) purposes but rather constituted an integral part of the Westcoast system. Hugessen J.A. concluded as follows:

In my view, the combination of ownership, direction and control in the hands of Westcoast, together with the other factors which I have enumerated above, lead ineluctably to the conclusion that

Ibid.

Dome, supra note 84 at 139 (para. 15).

Ibid. at 140 (para. 18); quoted with approval in Westcoast, supra note 3 at 295 (para. 34) [emphasis in original]. 
Westcoast is a single undertaking engaged in the interprovincial and international transportation of natural gas. As such, it is subject to federal jurisdiction. ${ }^{\text {s }}$

The analysis is clear. First, the gathering system is part of a single business enterprise, displaying unity of ownership, direction, and control. Second, that enterprise is extraprovincial in its scope of operations. The consequence, in jurisdiction terms, was to overturn the NEB's conclusion that the Westcoast gathering system was a matter of provincial jurisdiction under s. 92(10)(a).

If the intraprovincial gathering system and related facilities had not been subject to the same "ownership, direction and control" as the mainline system, the answer to the first question would have been different, as would the jurisdictional outcome of the case. This possibility is alluded to in Westcoast, where Hugessen J.A. states that

\begin{abstract}
a finding that the gathering and processing facilities owned and operated by Westcoast are a part of its transportation undertaking does not necessarily establish that the gathering and processing operations carried on by others are vital or essential to the Westcoast undertaking so as to become themselves subject to federal jurisdiction. ${ }^{*}$
\end{abstract}

Hugessen J.A. expresses no final opinion on how a case involving these other operations would be decided. His reasoning, following the Central Western approach, suggests that the provincial jurisdiction over gathering facilities not owned by Westcoast would be based on the fact that they are not "essential" to the core federal undertaking. The analysis of s. 92(10)(a) set out in this article supports the implication of his dicta that separately owned and operated facilities would not be characterized as part of the Westcoast undertaking, but bases this conclusion instead on the definition of undertaking. Separately-owned facilities could not, using the three unities test, be characterized as a part of Westcoast's extraprovincial undertaking. Rather, they constitute distinct, intraprovincial business operations and would not be brought within federal jurisdiction simply because of their functional similarity to the Westcoast gathering system.

\title{
2. Cases Upholding Provincial Jurisdiction
}

A number of the pipeline and railway cases where the undertaking was found to be within provincial jurisdiction also lend support for the approach proposed here. A leading example of these cases is the Supreme Court of Canada's decision in Central Western. This case involved a railway line that had been sold by Canadian National Railway (CN) to Central Western Railway Corporation. The line was 165 kilometres long and was situated entirely within Alberta.

Dickson C.J.C. applied the two-part test quoted at the beginning of this article ${ }^{97}$ to determine whether Central Western and $\mathrm{CN}$ constituted a single extraprovincial 
undertaking and whether, in the event of a negative answer to this question, the relationship between the two was sufficiently integral to bring Central Western within federal jurisdiction. His conclusion on both branches of the test was that the necessary relationship did not exist, notably because $\mathrm{CN}$ did not control the Central Western operations and it was not dependent on the services of Central Western.

This conclusion is consistent with the analysis of undertakings proposed here. The Central Western line was separately owned and operated and thus constituted a distinct business enterprise, not a part of the $\mathrm{CN}$ undertaking. Since its facilities and operations were entirely intraprovincial, the province has jurisdiction under s. 92(10)(a).

Support for this analysis can be found in the Central Western decision. Dickson C.J.C. discussed ownership and control, noting that the ownership of an enterprise is not conclusive in determining whether the operations at issue constitute a single undertaking. ${ }^{98}$ In his view, the key reason why $\mathrm{CN}$ and Central Western were two separate undertakings was the absence of what, in this article, is termed unity of control. He summarized his conclusion as follows:

In my view, while the factors mentioned by the respondents indicated a close commercial relationship between the two railways they do not show that $\mathrm{CN}$ operates Central Western. Rather, the sale of Central Westem [by $\mathrm{CN}$ ] has resulted in a fundamental change in the management of the rail line. Most notably, the difference is manifested in the daily control of the business of the rail line.... Basically, $\mathrm{CN}$ exercises no control over the running of the rail line, making it difficult to view Central Western as a federal work or undertaking.9

In other words, the separate ownership and control of the Central Western and CN railway operations would make it odd to conclude that they are a single business enterprise.

Dickson C.J.C.'s application of the "integral" test in Central Western also involved an examination of the nature of the relationship between $\mathrm{CN}$ and Central Western. ${ }^{100}$ His reasoning illustrates well the indeterminacy of the applicable principles. In fact, he stated that: "The principles ... are not intended to be applied in a strict or rigid manner; instead, the test should be flexible and attentive to the facts of each particular case."101 Dickson C.J.C. concluded his judgment as follows:

In my view, ... this Court's dicta consistently suggests [sic] that something more than physical connection and a mutually beneficial commercial relationship with a federal work or undertaking is required for a company to fall under federal jurisdiction. In my opinion, the requisite degree of integration is absent on these facts. ${ }^{102}$ 
This passage highlights, but does not answer, the two fundamental questions in the s. 92(10)(a) case law: (1) What is the "something more" that is required to found federal jurisdiction? and (2) How does one measure the "requisite degree of integration"? It thus demonstrates succinctly the inherent indeterminacy at the heart of the Central Western approach to s. 92(10)(a). The argument in this article is that the "something more" is unity of ownership, direction and control. Absent this three-fold unity, intraprovincial operations remain within provincial jurisdiction. As a result, there is no need to engage in the futile exercise of attempting to identify a generalizable and determinate test for measuring, across a broad range of fact situations, the "requisite degree of integration."

The Federal Court of Appeal's decision in Cyanamid is a second important s. 92(10)(a) case that concluded in favour of provincial jurisdiction. The pipeline at issue was to be constructed and operated by a subsidiary of Cyanamid Canada Inc. to connect its plant directly to the TCPL mainline. ${ }^{103}$ In this way, Cyanamid proposed to bypass the local distribution network.

MacGuigan J.A. concluded that the jurisdictional issue should be settled using the "essential" test. Since the TCPL system was in no way dependent on the Cyanamid bypass, he concluded that the latter came under provincial jurisdiction. ${ }^{104}$

Applying the approach proposed here yields the same jurisdictional result. The bypass was to be owned and operated by Cyanamid for the exclusive purpose of connecting its facilities to the TCPL mainline. Consequently, the proposed criteria for undertaking indicate clearly that it is a distinct business enterprise rather than a component of TCPL. Since Cyanamid's pipeline operation is situated entirely within Ontario, it is an intraprovincial undertaking coming within provincial jurisdiction.

This analysis of Cyanamid is supported by a passage in the judgment dealing with the Winner case. After discussing how Winner might be reconciled with the "necessary nexus" or "essential" test, MacGuigan J.A. stated that: "In fact, the closest parallel to the Winner situation in the instant reference would be an application by TCPL to build and operate the bypass pipeline as its own." 105 As noted by Hugessen J.A. in Westcoast, this passage "clearly implied that the result [in Cyanamid] would have been different if the bypass had been built and operated by the interprovincial undertaking."106 The reason is simply that it would then have been owned and controlled by TCPL and would serve a purpose entirely consistent with the direction of the TCPL system. Consequently, it would be a part of TCPL's extraprovincial business undertaking.

Cyanamid, supra note 12 at 202. Cyanamid Canada incorporated Cyanamid Canada Pipeline Inc. to construct and operate the bypass pipeline.

Ibid. at 221.

Ibid. at 218.

Westcoast, supra note 3 at 295 (para. 35). 
Finally, the proposed application of s. 92(10)(a) to undertakings is supported by the Consumers' Gas case, the facts of which were outlined briefly above. ${ }^{107}$ The court's finding in favour of provincial jurisdiction can be explained by the fact that the pipeline at issue was part of the Consumers' Gas Company Ltd. business enterprise, which operated an intraprovincial gas distribution system. As noted above, the court concluded that the Ottawa East Line was an intraprovincial work, and did not by itself constitute an undertaking. The relevant undertaking - the arrangement under which that work was operated - was Consumers' Gas, an intraprovincial business. The fact that the interprovincial link depended on the Consumers' Gas system, or some part of it, for its gas supply was insufficient to place some or all of that intraprovincial system under federal jurisdiction.

The court in Consumers' Gas made explicit reference to the second key point noted above in the discussion of Winner. ${ }^{108}$ Hugessen J.A. stated that:

It is well settled law that in constitutional inquiries of this sort the courts must take undertakings as they find them and not as they might be. It is clear to us ... that the Ottawa East Line is and has always been an integral part of Consumers' Ottawa distribution system; whether or not that system should itself be viewed as a separate undertaking (as opposed to being part of an even larger undertaking comprised of the various distribution systems operated by Consumers') it is constitutionally impermissible to break it into its constituent parts whose existence as independent undertakings is wholly notional. ${ }^{109}$

As in Westcoast, the enquiry focuses on the nature of the business enterprise as it in fact exists.

This interpretation of the Consumers' Gas case should be elaborated on in light of several facts referred to in the judgment that are germane to the test for undertakings proposed here. The court noted that Consumers' Gas, Gazifère Inc. (the Quebec retail distribution company) and Niagara Gas Transmission Ltd. were "affiliated companies with a common ownership." "10 The court did not comment further on this fact, although the passage just quoted alluded to the possibility that Consumers' Gas might be part of a broader undertaking - an issue not squarely before the court.

The case also includes a passage from the NEB decision that discusses the commercial relations between Consumers' Gas, Niagara Gas and Gazifère and notes that the Niagara line was to be constructed, operated and maintained by Consumers' Gas. This relationship raises the question of whether unity of control might be found among the three operations. Although this issue was not addressed by the court, relevant passages in the judgment suggest that it viewed these commercial and

Supra note 3, and specifically note 60 and associated text. Supra note 78 , and specifically note 82 and associated text. Consumers' Gas, supra note 3 at 153 (para. 7) (footnote omitted). In the footnote following the first sentence of this passage, Hugessen J.A. cites the Westcoast decision, supra note 3 at 281-82 (para. 23). This section of Wesicoast, in turn, includes the quotation from Winner that was reproduced at supra note 82.

Consumers' Gas, supra note 3 at 152 (para. 3). 
operational relationships as being at arm's length. In commenting on the commercial relationship, the court stated that "as a transportation entity Niagara could in a sense be said to be dependent on those who ship and those who receive the product transported in the same way that any commercial enterprise is dependent on its customers, but that is not dependency in the constitutional sense." "11 The court also referred to the "contractual arrangements" entered into by Niagara for the construction and operation of its line and said that they also were not constitutionally significant. ${ }^{12}$ While these passages apply the "essential" test analysis, it might be inferred that unity of control would have been found lacking had the court applied the approach proposed here. However, the brevity of the court's reasons and the fact that it applied the second test in Central Western means that this inference cannot be made with absolute certainty.

The unity of ownership, direction and control thus provides a theory that explains all of these cases. In each instance, the undertaking identified by the courts displayed this unity. In none of these cases did the courts find a single undertaking when any of these characteristics were absent.

\section{Hard Cases and the Three-Fold Unity Test}

One practical advantage of the proposed test for undertakings is that it corresponds well with the standard characteristics of business enterprises. The combination of ownership, direction and control is generally the defining characteristic of activities that constitute a single business. In practical terms, these common elements provide a means of distinguishing the operations of a single business from the relationship that exists when two separate businesses engage in mutually advantageous commercial transactions. This close correspondence with the reality of business organization means that in most fact situations, either the three unities will be found together or none will be present. However, in certain instances one or two may be present but there is uncertainty regarding the other(s). These somewhat unusual fact situations have given rise to some of the leading cases under s. 92(10)(a). The proposed approach, by highlighting the factual anomalies that gave rise to these cases, provides insight into why they have been viewed as hard cases. It can also be applied directly to the fact situations, yielding identical results in some instances and different ones in others.

Before turning to the cases, the generic fact patterns are briefly reviewed. It is important to bear in mind that the clear absence of any of the unities automatically disqualifies the activities in question from being a single undertaking. Hard cases arise, therefore, where there is doubt as to the existence of at least one characteristic.

First, there may uncertainty regarding unity of control, despite common ownership. This situation may arise where a single company engages in distinct operations or in the case of commonly-owned subsidiaries. It has been addressed in the s. 92(10)(a) case law, as summarized by Hogg: 
A company may engage in more than one undertaking, in which case that company's operations may become subject to dual legislative authority. The fact that various business operations are carried on by a single proprietor does not foreclose inquiry as to whether or not those operations consist of more than one undertaking for constitutional purposes. It is the degree to which the operations are integrated in a functional or business sense that will determine whether they constitute one undertaking or not. ${ }^{113}$

Even where common ownership exists, it is necessary to consider the degree of operational and functional integration between activities, the extent to which they are managed together, and the commonality of purpose when determining whether they constitute a single undertaking.

Second, in certain instances there may be uncertainty surrounding unity of ownership. Although this characteristic will generally be unproblematic, difficulties in characterization may arise where corporate structure is complicated and there is partially overlapping ownership.

Finally, there may be some instances where business activities are subject to common ownership and control but have fundamentally different directions or purposes. This situation is also likely to be rather unusual, since one would normally expect activities with different purposes to be separately managed. Furthermore, the purpose of an activity may be subject to different characterizations, often as a function of the pattern of ownership and control. This characteristic is therefore likely to be the most elastic of the three, and in practice few cases will turn on it.

The proposed test for undertakings can now be applied to a series of s. 92(10)(a) cases which raise questions regarding the presence of one or more of these three characteristics. The facts of these cases are sometimes unusual, in that they deviate from the standard pattern where business entities clearly exhibit the three-fold unity of ownership, direction and control. For this reason, they provide an interesting context for evaluating the three unities approach.

The Empress Hotel case concerned jurisdiction over labour relations at a hotel owned by Canadian Pacific Railway. ${ }^{114}$ The Privy Council held that the hotel was not part of the company's extraprovincial railway but rather constituted a separate undertaking engaged in the general hotel business. It explained its finding as follows:

It may be that, if the appellant chose to conduct a hotel solely or even principally for the benefit of travellers on its system, that hotel would be part of its railway undertaking. Their Lordships do not doubt that the provision of meals and rest for travellers on the appellant's system may be a part of its railway undertaking whether that provision is made in trains or at stations, and such provision might be made in a hotel. But the Empress Hotel differs markedly from such a hotel. Indeed there is little if anything in the facts stated to distinguish it from an independently-owned hotel in a similar position. No doubt the fact that there is a large and well-managed hotel at Victoria tends to increase traffic on 
the appellant's system; it may be that the appellant's railway business and hotel business help each other, but that does not prevent them from being separate businesses or undertakings."

Applying the three-fold unity test for undertakings, there is no doubt that the hotel and the railway had unity of ownership. The Privy Council's reasons are clear, however, that they lacked unity of direction or purpose: one undertaking was in the general hotel business while the other was concerned with transcontinental rail travel. The case is unclear regarding the control and management issue, although it is reasonable to surmise that the railway and hotel may have been separately managed. Consequently, the approach proposed here would yield the same result as reached by the Privy Council: the Empress Hotel and the extraprovincial railway do not constitute a single undertaking.

As second illustrative case is Luscar Collieries Ltd. v. McDonald. ${ }^{116}$ At issue was a jurisdiction over a railway branch line that was built and owned by a colliery. The branch line connected with the interprovincial operations of Canadian Northern Railway (CNR), which operated the line under the terms of an agreement with the owner. The Privy Council, in a rather ambiguous judgment, ${ }^{117}$ concluded that the branch line was part of a single extraprovincial undertaking. Interestingly, the Privy Council expressly reserved judgment on the question of whether the same conclusion would be reached should CNR cease to operate the line. In subsequent cases, the Supreme Court of Canada stated that the key to Luscar was common management of the two lines. ${ }^{118}$ The implication is that the absence of unity of control would lead to a conclusion that the two lines were separate undertakings, one intraprovincial and the other extraprovincial.

Applying the three-fold unity test to the facts as described above, Luscar would probably be decided differently. While unity of control or management and unity of direction were present, the different ownership of the two railways would appear to preclude a finding that they constituted a single undertaking. One additional element of the Luscar facts, however, casts some doubt on this conclusion and suggests that the decision may in fact be reconcilable with the proposed test for undertakings. The arrangement between the coal company and CNR provided that the ownership of the branch line would be transferred to CNR following reimbursement of the coal company by way of freight rebates. ${ }^{119}$ Consequently, unity of ownership was explicitly anticipated by the arrangement under which the line was built and operated. This fact might be relied on to bring the result dictated by the three unities test for undertakings into line with the Privy Council's conclusion. ${ }^{120}$

\footnotetext{
Ibid. at 732.

[1927] 4 D.L.R. 85 (J.C.P.C.) [hereinafter Luscar].

See Hogg, supra note 11 at 576.

B.C. Elec. Ry. Co. v. C.N.R., [1932] S.C.R. 161 at 169; Central Western, supra note 12 at 1132-33.

Luscar, supra note 116 at 86-87.

In Central Western, supra note 12 at 1133, Dickson C.J.C. distinguished Luscar on the grounds that " $\mathrm{CN}$ does not operate Central Western nor does it have any future plan or expectation to take over the railway, as was the case in Luscar."
} 
A third important s. 92(10)(a) case where unity of ownership, direction and control were absent is the Stevedoring Reference. ${ }^{121}$ The case concerned jurisdiction over a company that provided stevedoring and terminal services for ships engaged in the extraprovincial transport of goods. The stevedoring company was, however, separately owned and operated from the shipping lines and its operations had no extraprovincial component. The Supreme Court of Canada concluded that the stevedoring operations were within federal jurisdiction by virtue of their close relationship with the shipping undertaking, the latter being dependent on the former.

As with Luscar, the interpretation proposed here suggests a different result. If the test is unity of ownership, direction and control as opposed to the "integral" or "essential" relationship between operations, the stevedoring company is clearly a separate undertaking. The Stevedoring case may, however, turn out to be a relatively weak precedent in terms of the proposed analysis. First, it may be distinguished on the grounds that federal jurisdiction over stevedoring might also be based on s. 91(10), the "navigation and shipping" power. ${ }^{122}$ Second, one may question its consistency with the "freight forwarder" cases under s. 92(10)(a), which found that the business of collecting freight in a province for the purpose of shipping it outside of the province by extraprovincial railway was within provincial jurisdiction. ${ }^{123}$ Consequently, the Stevedoring case is not necessarily inconsistent, at least in its result, with the three unities test for undertakings under s. 92(10)(a).

This review of the case law indicates that reliance on unity of ownership, direction and control as the defining characteristics of undertakings yields results that are consistent with a significant body of the s. 92(10)(a) case law. Where this reliance would have produced a different result, the explanation for the outcome is clear. This clarity is, in fact, a principal advantage of the proposed approach. Under a wide range of fact situations, it provides a bright line test for identifying the relevant undertaking. Once identified, the characterization as either intraprovincial or extraprovincial is generally unproblematic.

It is suggested, therefore, that this approach would significantly reduce the scope for jurisdictional uncertainty. There will, of course, continue to be hard cases. The type of issues that these are likely to raise can, however, be defined with some precision. These hard cases will arise only where there is room for debate about whether one or more of the three unities is established. Furthermore, as noted above, in any case where one of the unities is not present, there is no single undertaking. Consequently, the categories of hard cases can be further narrowed: uncertainty will only exist where there is doubt as to one or more of the unities and where it is clear that the other, or others, are present.

$122 \quad$ Hogg, supra note 11 at 577.

123 These cases are discussed by Dickson C.J.C. in Central Western, supra note 12 at 1146-47. See, in particular, the passage quoted from In re Cannet Freight Cartage Lid., [1976] I F.C. 174 at $177-78$. 
For example, it remains to be seen how the unity of ownership criterion would be applied in cases of overlapping corporate ownership. Situations where one company owns part of another may raise difficult questions regarding unity of ownership when, and only when, unity of direction and unity of control are also present. Likewise, there may be cases of unity of ownership and control where debate is possible regarding unity of direction or purpose. Finally, the related company issue may complicate the picture in cases where unity of ownership and direction are clear, but management or control may be separated between distinct corporate entities (e.g., subsidiaries).

Over time, these issues can be expected to be resolved as case law accumulates and the courts set out the applicable principles in greater detail. These principles should include guidance on issues that are likely to recur, such as overlapping ownership of business operations. In addition, general doctrines of constitutional interpretation will be applied to hard cases. For example, the doctrine of colourability will allow the courts to address cases where, for example, an interprovincial undertaking is artificially segmented into separate units for the purpose of avoiding federal jurisdiction. There is already clear authority in the s. 92(10)(a) cases for this application of the colourability doctrine. ${ }^{124}$

Given the wide variety of corporate structures, there will inevitably be cases leading to litigation. Resort to the courts in hard cases is inevitable, and it is doubtful that any approach to s. 92(10)(a) could eliminate this possibility by anticipating and addressing all possible fact situations in advance. It is suggested, however, that the scope for litigation under the proposed approach is far more limited than under the Central Western test for s. 92(10)(a).

\section{SUMMARY AND EVALUATION}

This review of the leading s. 92(10)(a) cases shows that they are largely or entirely consistent with the theory that the courts first identify the undertaking and then determine if it is intraprovincial or extraprovincial. Most importantly, the cases that found in favour of federal jurisdiction do not, it is argued, apply s. 92(10)(a) to bring "intraprovincial" undertakings into federal jurisdiction. Westcoast, Flamborough, and Dome each involved one undertaking, and in each case it was an extraprovincial business enterprise. Likewise, even the relatively close physical and operational connections between intraprovincial and extraprovincial enterprises in Central Western, Cyanamid, and Consumers' Gas did not lead the courts to conclude that separate intraprovincial businesses should be swept into federal jurisdiction by s. 92(10)(a). Finally, the proposed approach provides insight into, and a satisfactory means of deciding, fact situations that give rise to hard cases under the traditional approach to s. 92(10)(a).

The four criteria set out at the beginning of the article can now be returned to for a final assessment of the merits of the proposed approach to undertakings. First, the interpretation presented above reflects the structure of s. 92(10)(a) by focusing on the 
identification of undertakings and their interprovincial or extraprovincial character as the key determinant of jurisdiction. It is also consistent with the distinction between works and undertakings, providing an intelligible basis for determining what constitutes an undertaking.

Second, it yields results that are consistent with the outcomes in many of the leading pipeline and railway cases. Those cases where a different outcome would likely be reached arguably exhibit anomalous fact situations, in the sense that they could be distinguished, decided on different grounds, or simply represent an unusual arrangement whereby activities exhibit some, but not all, of the three unities.

Third, this approach holds the promise of much greater certainty in the determination of jurisdiction under s. 92(10)(a). As illustrated by the cases discussed above, the relevant business enterprise is, in most cases, relatively easy to identify once the issue is framed in terms of unity of ownership, control, and direction. Furthermore, once the undertaking is identified, it is usually quite clear whether it is engaged in an interprovincial or extraprovincial business. There will, of course, be certain types of fact situations that are potentially more problematic. Nonetheless, the approach proposed here would have provided a clear answer in a number of cases that, under the conventional interpretation, were sufficiently uncertain that resolution by the Federal Court of Appeal or the Supreme Court of Canada was required.

Finally, the proposed approach to undertakings yields results that make sense from regulatory and federalism perspectives. As a matter of regulatory policy, there are practical advantages to subjecting a given business enterprise to the primary authority of one level of government under s. 92(10)(a). Regulatory and business complications would undoubtedly have resulted from a decision which, for example, placed the Ottawa East Line under federal jurisdiction while leaving the rest of the Consumers' Gas system to be provincially regulated. The division of Westcoast Energy Inc.'s pipelines and associated facilities into a federally-regulated mainline system and a provincially-regulated gathering network could also complicate both business and regulatory affairs. While these complications would probably not have been insurmountable, the appeal of an approach that treats undertakings consistently in terms of primary jurisdiction is undeniable. In fact, the principle of a single regulator has been recognized by the courts in the current $s .92(10)(a)$ jurisprudence. ${ }^{125}$

The proposed interpretation is also consistent with federalism values. Undertakings that confine their operations to a single province can be effectively regulated by that province, while those with extraprovincial activities are more appropriately subject to federal jurisdiction. This result makes sense in terms of regulatory competence - there are no constitutional "gaps" - and it provides the federal government with authority communication undertaking is subject to the regulation of only one level of govemment." As Dickson C.J.C. stated in $A G T$, supra note 23 at 409, the question of jurisdiction "is an all or nothing affair." 
over the principal national components of the transportation system. It should be noted, however, that certain intraprovincial undertakings (e.g., gathering systems) may be of fundamental importance to the national transportation system. Assigning primary jurisdiction over these undertakings to the provinces under s. 92(10)(a) does not completely tie the federal government's hands should they be operated or regulated in a way that threatens serious harm to national interests. Section 92(10)(c) of the Constitution explicitly grants authority to Parliament to declare intraprovincial works to be "for the general advantage of Canada," thereby bringing them within federal jurisdiction. Furthermore, as argued elsewhere, federal action to protect the Canadian economic union can be taken under the general branch of the "trade and commerce" power. ${ }^{126}$ In the pipeline context, federal trade and commerce jurisdiction could support the regulation of intraprovincial gathering systems to the extent necessary to ensure the free flow of oil and gas to Canadian and foreign markets. Finally, political and administrative arrangements, notably interdelegation, offer further means of injecting flexibility into the judicially-determined division of powers.

\section{THE NOVA EXAMPLE}

A brief review of the jurisdictional issues relating to the NOVA pipeline system in Alberta illustrates how the approach to s. 92(10)(a) proposed above can be applied to a significant component of Canada's energy infrastructure. The gathering system owned and operated by NOVA Gas Transmission Ltd. (NGTL) is the primary system for transporting natural gas from processing facilities to delivery points within Alberta and to border stations for export. NGTL has 21,400 kilometres of pipeline, 48 compressor stations, 927 receipt points and 163 delivery points. It employs approximately 2,740 people in 90 communities in Alberta.

NGTL delivered 4.3 trillion cubic feet of natural gas in 1995, approximately 80 percent of Canadian natural gas production and an amount equivalent to 15 percent of all natural gas produced in North America. Market deliveries of gas transported by NGTL in 1995 were divided between Alberta (15 percent), British Columbia (1 percent), Eastern Canada (26 percent) and the United States (58 percent). Gas exports are transmitted by NGTL to sausage-link pipelines or to interprovincial and international mainlines at points within Alberta. NGTL also handles some gas that is gathered from reservoirs in British Columbia. ${ }^{127}$

NGTL is a wholly-owned subsidiary of NOVA Corporation (NOVA). ${ }^{128}$ Other members of the NOVA corporate family include Foothills Pipelines, an extraprovincial mainline system that receives gas from the NGTL system in Alberta and delivers it to points in the United States. Foothills is 50 percent owned by NOVA. In addition, NOVA owns a majority stake in Novagas Clearinghouse Limited Partnership and

\footnotetext{
$126 \quad$ Kennett, supra note 23 at 31-36.

127 The factual information in this section was obtained from the NGTL "Fact Card" (31 December 1995) and "NOVA at a Glance," available through the NOVA Home Page (http://www.nova.ca). Information on the NOVA corporate structure is taken from NOVA Corporation 1995 Annual Report at 8-9.
} 
related companies which operate a gathering network in northeastern British Columbia that crosses into Alberta and connects with the NGTL system.

These characteristics make NGTL, and the NOVA group of companies as a whole, an interesting case study for the application of the transportation power. NGTL has always been provincially regulated, although the issue of jurisdiction over this system as been termed a "perennial question" by one commentator. ${ }^{29}$ Foothills Pipelines and Novagas Clearinghouse are federally regulated. The question of whether all or part of NGTL will be found to be within federal jurisdiction is a live issue, having already been raised at two NEB hearings. ${ }^{130}$ The NEB's reference to the Federal Court of Appeal regarding the operations of Novagas Clearinghouse would have shed further light on this subject, had it been heard by the Court. ${ }^{131}$

As is argued in more detail elsewhere, the approach proposed in this article provides a clear answer to the traditional arguments for federal jurisdiction over NGTL. ${ }^{132}$ This analysis can be briefly summarized as follows. First, individual NGTL pipelines are intraprovincial works, being situated entirely within Alberta. Second, the fact that NGTL is operationally connected with extraprovincial pipelines and is therefore integral, and arguably essential, ${ }^{133}$ to their operation is not sufficient to being it within federal jurisdiction. NGTL's pipelines and facilities are characterized by unity of ownership, direction and control. Since its operations are entirely within Alberta, the interpretation proposed here suggests that NGTL would be characterized as an intraprovincial undertaking subject to provincial jurisdiction under s. 92(10)(a).

This response to the traditional arguments relating to NGTL does not, however, fully resolve the jurisdictional issue in light of relatively recent changes in the corporate structure and operations of the NOVA group of companies. As noted above, NGTL is a subsidiary of NOVA. NOVA is also the majority owner of the Novagas Clearinghouse gathering system that moves gas from British Columbia into Alberta and connects with the NGTL system. The issue is therefore whether the operations of Novagas Clearinghouse will result in both it and NGTL being viewed as a single extraprovincial - undertaking. Driving this issue is the fact that shippers benefit from NGTL's postage stamp rates once their gas enters the provincially regulated Alberta system, whereas shippers whose gas is transported by the federally regulated Westcoast Energy Inc. must pay distance-based tolls. There is thus a significant commercial incentive for Westcoast to argue that NGTL should be brought under federal regulation and made subject to a distance-based toll structure.

Determination of the status of NGTL in relation to Novagas Clearinghouse raises potentially difficult issues, noted above, regarding the three unities of ownership, direction, and control. No definitive answer to these questions will be offered here. 
However, if the proposed approach to s. 92(10)(a) is adopted, the issues before the courts and the type of evidence required to resolve these issues can be identified with considerable precision. The two key questions centre on unity of ownership and unity of control. Questions may also be raised regarding unity of purpose, but this issue is not likely to be determinative.

The ownership question is whether NOVA's 100 percent stake in NGTL and its majority holding in Novagas Clearinghouse constitute unity of ownership over the two entities. There is little in the case law on which to base a clear prediction of how this question would be answered. On the one hand, the court may conclude that the distinction between overlapping and common ownership is significant and that, despite having a major shareholder in common, NGTL and Novagas Clearinghouse are separately-owned corporate entities.

The court may, however, take the view that the controlling interest of NOVA in both entities is sufficient to constitute unity of ownership. Furthermore, the court may be obliged to address arguments regarding the possible colourability, in constitutional terms, of the NOVA corporate structure. Novagas Clearinghouse is clearly connected with NGTL through the NOVA corporate family and its expanding operations in British Columbia may be seen as having the practical effect of extending the tentacles of the NGTL gathering system across a provincial border. As the Novagas Clearinghouse network expands in British Columbia, arguments may well be made that the separate corporate structure should not be determinative of the constitutional issue. Those seeking federal jurisdiction over NGTL may well cite Mahoney J.A.'s dicta in the Dome case that "federal jurisdiction is not to be avoided simply by the vesting of a portion of a single undertaking in a subsidiary." 134

Even if unity of ownership is found, however, the question remains whether there is unity of control. As indicated in the general discussion of this criterion, this issue will turn on findings relating operational coordination and common management. If NGTL and Novagas Clearinghouse have separate organizational structures and their business relationship is conducted following arm's length commercial practices, the argument that unity of control is absent would be strengthened. However, if they are subject to common management and close operational coordination within the NOVA corporate family, it would be more difficult to contest the existence of unity of control.

Finally, application of the proposed approach raises the issue of unity of direction. The characterization of the respective purposes of the NGTL and Novagas Clearinghouse operations may, in practice, follow from findings relating to ownership and control. On the one hand, the purpose of NGTL may be characterized as the operation of an intraprovincial gathering system, while Novagas Clearinghouse is directed towards a niche in the interprovincial gas market. Alternatively, it might be argued that NOVA as a whole is operating a single pipeline system, the purpose of which is to move gas within Canada and internationally. On this characterization, the components of the NOVA family would have a common purpose, demonstrated by the 
fact that gas can be shipped into Alberta from British Columbia (via Novagas Clearinghouse), through Alberta (via NGTL) and into the United States (via Foothills) without ever leaving the NOVA family of companies.

The NOVA example thus illustrates both the advantages and the remaining uncertainties associated with the proposed approach to the transportation power. While the interpretation outlined above provides clear answers to the traditional arguments regarding jurisdiction over NGTL, the evolving structure of NOVA as a whole, notably through its transboundary operations in northeast British Columbia and northwest Alberta, raise new issues as to whether NGTL will continue to be seen as a distinct intraprovincial undertaking, as opposed to forming part of a larger extraprovincial one. The NOVA facts thus provide a classic hard case for the proposed approach to $\mathbf{s}$. 92(10)(a). The issues raised in this context highlight the need for a clear judicial statement of the criteria for identifying the relevant undertaking for s. 92(10)(a) purposes in cases of common or overlapping ownership. Should jurisdiction over NOVA come before the courts, a carefully reasoned judgment that addresses these issues directly would go a long way in resolving the remaining areas of uncertainty surrounding s. 92(10)(a).

\section{CONCLUSION}

The transportation power, particularly as applied to pipelines, has thus far eluded a satisfactory interpretation. Ongoing litigation and the apparent inability of the currentlyaccepted legal principles to provide clear guidance have led to the suggestion that jurisdictional certainty can only be achieved through a political and administrative solution.

This article has argued that it is premature to conclude that the relevant legal principles are clearly settled and that s. 92(10)(a) is unworkable. A review of the case law from a new perspective yields, it is suggested, an interpretation that promises greater certainty. This approach begins with the conceptual distinction between works and undertakings. In each case, it follows a two step analysis, first identifying the relevant work or undertaking and then determining whether it is intraprovincial or extraprovincial. As well as being logically coherent, the proposed approach is generally consistent with the jurisprudence. It reveals an underlying structure in these cases that the courts have followed but failed to articulate clearly.

While this approach provides a clear framework for answering the jurisdictional question in many s. 92(10)(a) fact situations, uncertainty remains in situations where business activities are commonly owned through subsidiaries or related companies. In these instances, guidance from the courts is required to clarify whether, and in what circumstances, the courts will look behind the corporate structure to find a single undertaking. The Westcoast appeal before the Supreme Court of Canada, and the possibility of future litigation relating to jurisdiction over Novagas Clearinghouse, may provide the courts with an opportunity to address these issues in the next couple of years. 
Even if the approach proposed here fulfils the promise of providing greater jurisdictional certainty, some litigation will continue and there may be a need for political and administrative arrangements to adjust the regulatory system. Canadian federalism, in both law and practice, has long ago abandoned the conceptually tidy notion of "watertight compartments" in favour of the more dynamic - and realistic model of functional concurrency and intergovernmental accommodation. Divided jurisdiction over Canada's energy infrastructure suggests that a degree of cooperation between regulators is desirable. In some instances, consolidation of regulatory authority through the mechanism of interdelegation may provide the optimal solution.

It is not too much to expect, however, that constitutional law should provide a means of determining jurisdiction in a wide variety of fact situations without the need for ongoing facility-by-facility litigation. The interpretation of s. 92(10)(a) outlined in this article provides one approach for achieving a judicial solution to the jurisdictional uncertainty that currently pervades the regulation of pipelines. 